Article

\title{
From Cell to Battery System in BEVs: Analysis of System Packing Efficiency and Cell Types
}

\author{
Hendrik Löbberding ${ }^{1, *(\mathbb{D}}$, Saskia Wessel ${ }^{2}$, Christian Offermanns ${ }^{1}{ }^{(\mathbb{D}}$, Mario Kehrer ${ }^{1}{ }^{1}$, \\ Johannes Rother ${ }^{3}$, Heiner Heimes ${ }^{1}$ and Achim Kampker ${ }^{1}$ \\ 1 Chair for Production Engineering of E-Mobility Components, RWTH Aachen University, \\ 52064 Aachen, Germany; c.offermanns@pem.rwth-aachen.de (C.O.); m.kehrer@pem.rwth-aachen.de (M.K.); \\ h.heimes@pem.rwth-aachen.de (H.H.); a.kampker@pem.rwth-aachen.de (A.K.) \\ 2 Fraunhofer IPT, 48149 Münster, Germany; saskia.wessel@ipt.fraunhofer.de \\ 3 Faculty of Mechanical Engineering, RWTH Aachen University, 52072 Aachen, Germany; \\ johannes.rother@rwth-aachen.de \\ * Correspondence: h.loebberding@pem.rwth-aachen.de
}

Received: 7 November 2020; Accepted: 4 December 2020; Published: 10 December 2020

check for updates

\begin{abstract}
The motivation of this paper is to identify possible directions for future developments in the battery system structure for BEVs to help choosing the right cell for a system. A standard battery system that powers electrified vehicles is composed of many individual battery cells, modules and forms a system. Each of these levels have a natural tendency to have a decreased energy density and specific energy compared to their predecessor. This however, is an important factor for the size of the battery system and ultimately, cost and range of the electric vehicle. This study investigated the trends of 25 commercially available BEVs of the years 2010 to 2019 regarding their change in energy density and specific energy of from cell to module to system. Systems are improving. However, specific energy is improving more than energy density. More room for improvements is thus to be gained in packaging optimization and could be a next step for further battery system development. Other aspects looked at are cell types and sizes. There, a trend to larger and prismatic cells could be identified.
\end{abstract}

Keywords: electric vehicle battery; energy density; specific energy; packing efficiency; system design; cell type; BEV; battery engineering

\section{Introduction}

Every year, more and more electric vehicles are being put on the road. Increasing demand is supported by many forms of government subsidies, falling prices for vehicles and increasing offerings by the vehicle manufacturers are encouraged and mandated through continuously stricter $\mathrm{CO}_{2}$ fleet emission targets. To further increase the amount of battery electric vehicles (BEVs) sold, it is important to overcome hurdles such as the long charging times and the lower range of BEVs compared to Internal Combustion Engine (ICE) vehicles. Since especially range is very price sensitive due to the high cost of the battery, a competitive BEV price is one of the key factors for a widespread adoption of BEVs [1]. Falling prices for electric vehicles are mostly realized through savings in cost for the most expensive component of the electric vehicle, the battery system, which is estimated to make around $27 \%$ of the vehicle cost structure when assessing a long-range electric vehicle with $75 \mathrm{kWh}$ of energy [2] (p. 12). In 2019, prices for battery systems in BEVs are estimated to stand at $139 € / \mathrm{kWh}$ [3]. Now however, it is estimated that prices will fall to $122 € / \mathrm{kWh}$ in 2020 [2] (p. 12). This is already lower than the estimated price of $150 \$ / \mathrm{kWh}$ when electric vehicles can be price competitive with for example $50 \%$ of the US car market not only from a TCO (total cost of ownership) perspective, but from an initial price point 
perspective. It is believed that going significantly below this point will lead to widespread adoption of EVs [4]. However, it can also be noted that the relative and absolute price decrease rates for battery systems are slowing down [5] (p. 31). This raises the question, where the future price optimization next to the possible material improvements in the cell chemistry [6] (pp. 283-285) and production scaling effects [7] (p. 297) can come from.

Standard battery systems that power electrified vehicles are composed of individual cells, modules and together they form with the housing, thermal management and electric components a battery system. The modules consist of multiple cells connected in series and/or parallel, encased in a mechanical structure. A battery system is assembled by connecting multiple modules together in series or parallel with sensors and controllers including battery management systems and thermal management systems, and then encased in a housing structure as a final battery product designed specifically for each electric vehicle model [7] (p. 291).

The characteristics of a battery cell play a pivotal role in the overall performance of BEVs. Research on the optimization of the battery cell chemistry level has magnified strongly in the last decade. Large incremental improvements, even with traditional lithium-ion batteries, have been made, not only from a cost but also from an efficiency and lifetime perspective, which are all important critical parameters for batteries. Especially the energy density on cell level is expected to raise further from $263 \mathrm{Wh} / \mathrm{kg}$ [8] (p. 4) in 2020 in large volume products to beyond $370 \mathrm{Wh} / \mathrm{kg}$ until 2024 [9] (p. 12), [10]. When looking at the whole cell and not the electrode and material level, the variation is very large: cell sizes used in current electric vehicles on the market range from $3.5 \mathrm{Ah}$ [11] (pp. VIII-32) to beyond $120 \mathrm{Ah} \mathrm{[12].} \mathrm{Next} \mathrm{to} \mathrm{the} \mathrm{many} \mathrm{different} \mathrm{cell} \mathrm{chemistries} \mathrm{with} \mathrm{differences} \mathrm{in} \mathrm{cost,} \mathrm{electrical}$ behavior and lifetime, there are various types of cell formats such as pouch, cylindrical and prismatic cells [5] (p. 12), [13], (p. 3) with different shapes and casing materials that influence the design of the battery system with their distinct characteristics [14] (p. 183), like shown in Figure 1.
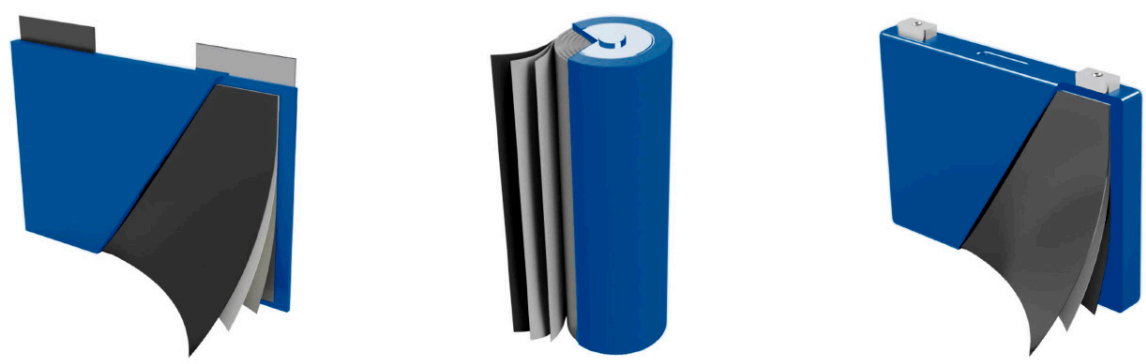

Figure 1. Typical Cell Types for Lithium Ion Batteries. From left to right: Pouch Cell, Cylindrical Cell and Prismatic Cell.

There is-so far-no consensus on using only one of the 3 different cell types, because they are all being used by the various Original Equipment Manufacturers (OEMs). Hence, the overall battery system topology varies greatly between different battery electric vehicle OEMs.

This raises the question, whether all these different design approaches are feasible or if a trend towards a single most useful cell and system design is emerging. How can a cost- and range optimal design be achieved on a system level? The aim of this work is a thorough review of current data on battery system design structures of mass-produced BEVs. Special consideration shall be given to packing densities and to cell type, size, use of space and weight of the battery system in current battery electric vehicles. In this paper, we used the collected data to find potential areas of further battery system optimization. By comparing the cell level to module and system level, we were able to see whether the improvements made on cell level are also implemented on module and system level or, if due to inefficient implementation, those improvements are getting lost on these levels. This paper also investigates, how cell type and cell size affect energy density and specific energy on module and system level. Like Jung, Silva et al. [15], it aims to find correlations and trends over multiple vehicles, 
but taken from a vehicle and battery system level to a battery system and component level. The result of this study will help to show where optimization potentials for battery systems in BEVs especially from a packaging and system design perspective are.

\section{Materials and Methods-Battery Data}

To achieve this, it was necessary to carry out a widespread assessment of electric vehicle battery systems on the market. For this, available data for as many electric vehicle battery systems as available from OEMs were aggregated from research papers, reports, conference presentations and websites. Due to the fact that data on vehicles is not easy to find, it has to be noted that the aggregation of the data was a combinatorial effort. Some sources give information on cell and module sizes of a vehicle, others for example only on the system design. This data was then assembled into a full battery system data set of the respective electric vehicle. In this paper, only the complete data sets are shown; whenever raw data was incomplete, the vehicle was omitted from the study. An overview of the type of data collected is given in Table A1 in the Appendix A.

Once aggregated, the data was then checked for plausibility and accuracy. Whenever multiple, conflicting values existed, the more likely configuration was employed or, when one source was official, this source was taken into account. Based on this large scale data collection, multiple classic battery key performance indicators (KPI) where calculated for each battery system. These indicators where calculated on cell, module and system level (Table A2 in Appendix A). Having thus gained a dataset on the battery systems, it is possible to assess how different design configurations correlate with the overall battery system KPIs. Then, the aim was to answer multiple questions:

1. How well is available space and mass utilized? The better the usage of volume available, the less material next to the cell needs to be used. This saves weight and increases range as well as saves costs, decreases the module size or leaves more space for further battery cells and thus more range. This assessment can be done between cell and system level but also between cell and module level and both from a gravimetric and volumetric perspective.

2. Are smaller or bigger cells beneficial to reach higher energy densities? Like the cell types, the cell size also varies a lot between the different manufacturers.

3. How do different cell types perform from a gravimetric and volumetric perspective? As mentioned, there is currently no industry consensus on one of the three types.

4. Which system level design shows the most potential for further optimization? A faster advancement in battery technology with a decrease in price will lead, as mentioned before, to a faster adoption of BEVs. Finding areas for potential optimizations will help to show battery system developers where to focus on in the future.

\section{Results}

In the dataset, 25 different BEVs from 10 different OEMs with start of production (SOP) years between 2010 and 2019 where analyzed regarding their specific energy, energy density, cell types, and cell size. The vehicles looked at are mainly European, American and Asian vehicles excluding Chinese vehicles because solid data there is scarce and hard to verify.

\subsection{Development of Energy Density and Specific Energy}

The energy density is one of the key indicators of performance of battery systems. Sufficient energy density allows for sufficient range and is especially focused at the development on cell level.

\subsubsection{Overall Development}

To understand the development of battery systems over the years, Figures 2 and 3 show the development of specific energy and energy density over the associated start of production (SOP) year of the respective vehicle on all possible levels (cell, module and system). 


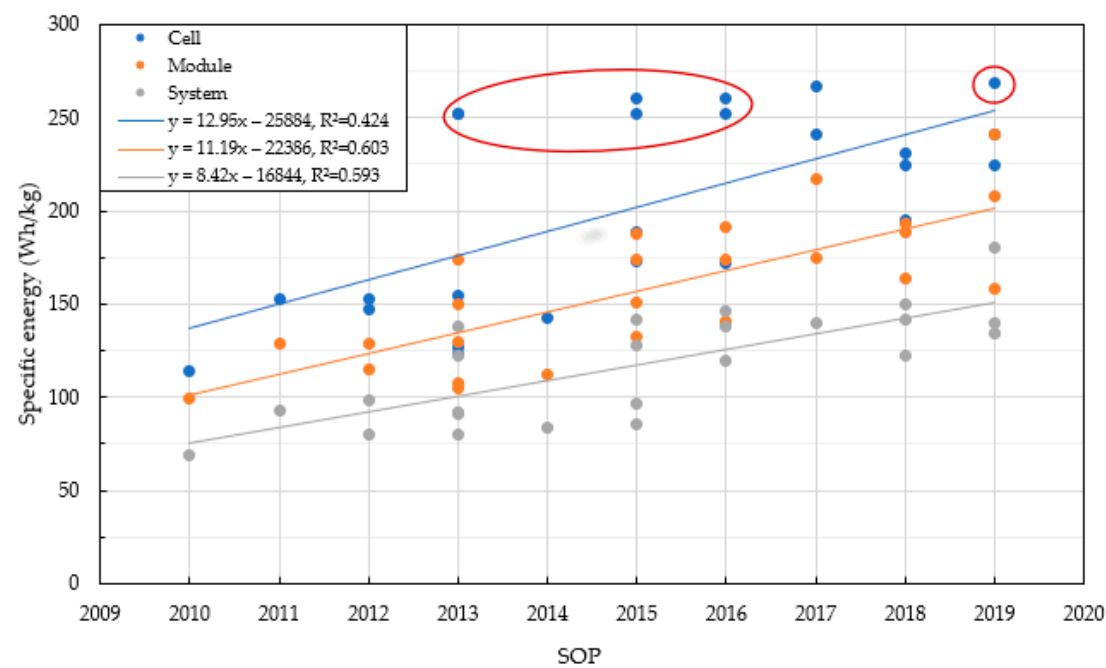

Figure 2. Development of the specific energy ( $\mathrm{Wh} / \mathrm{kg}$ ) in the years between 2010 and 2019. Blue represents the development on cell level, orange represents the module level, and grey represents the system level.

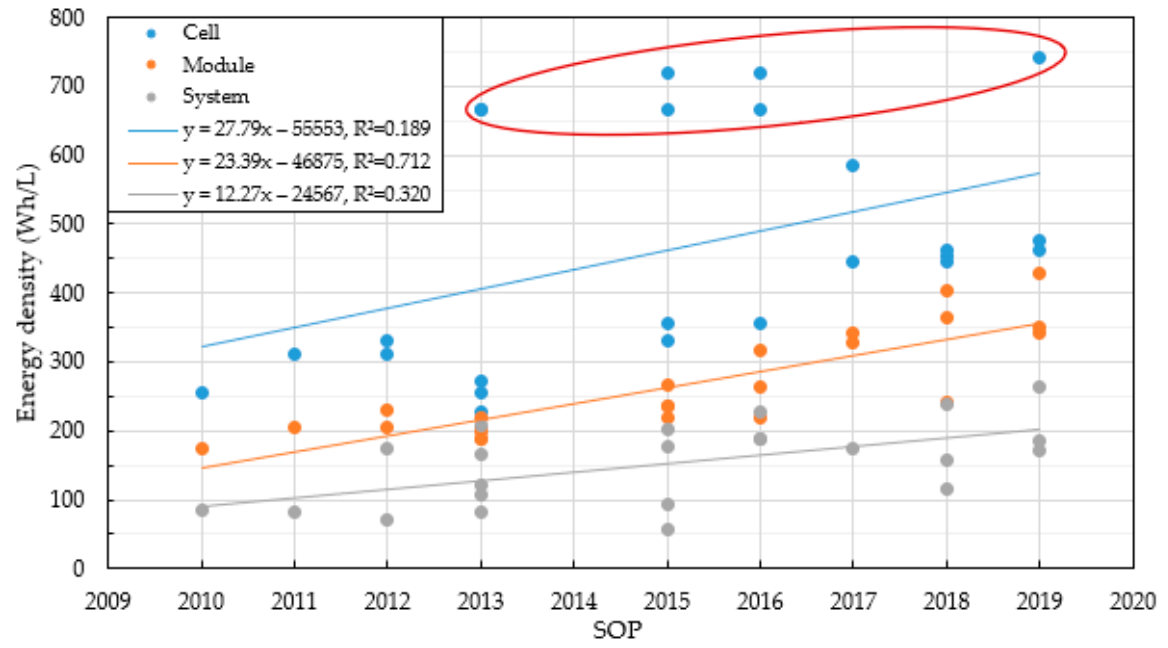

Figure 3. Development of the energy density (Wh/L) in the years between 2010 and 2019. Blue represents the development on cell level, orange represents the module level, and grey represents the system level.

It is noteworthy, that both graphs show the same trend of increasing energy density over the last years. In each graph, three linear regression lines are presented: the blue line is fit to the cell level, the orange is fit to the module level and the grey line is fit to the system level. The reason for choosing linear equations as a fit is the fact that typical "technology prediction" literature like [9] (p. 12) showcase a qualitatively linear development forecast of future energy densities of lithium-ion batteries and thus it makes sense to use the same proxy for comparing it to the actual development of battery systems.

Looking at the correlations $\left(\mathrm{R}^{2}\right)$ for an assumed linear regression line of both figures, large variations can be found. While the gravimetric energy density shows more constant correlations which vary between $0.42<\mathrm{R}^{2}<0.60$ if cell, module and system level are compared, the volumetric energy density varies between $0.18<R^{2}<0.72$ between these. The smallest correlation in both graphs can be found on cell level (gravimetric: $R^{2}=0.424$; vol.: $R^{2}=0.189$ ). The reason for this weak correlation are the battery cells used by Tesla (circled in red) which create the decreased correlation because they have a much higher energy density than others already since 2013. 
If one would exclude the data of the Tesla vehicles, the linear regression lines change: for the gravimetric energy density on cell level it would be $y=14.095 x-28221, R^{2}=0.753\left(R^{2}\right.$ increase of 0.329 ); for the volumetric energy density on cell level $y=28.171 x-56393, R^{2}=0.694$ (increase of 0.505 ). On module and system level however, there were only minor changes of $R^{2}$ (less than 0.1 ) found between the regression line of all cars and non-Tesla cars. This means, that all the non-Tesla vehicles correlate much more with each other than these vehicles with Tesla. The weakest correlation and the smallest slope can now be found on system level in both graphs. With $\mathrm{R}^{2}=0.32$ for the volumetric energy density, the correlation is very weak on system level.

Because the Tesla-vehicles have a large deviation from the other systems, especially on cell level, they will be listed separately on the following graphs, similar to [15]. The correlation between the values could also be interpreted as an indicator of how much the OEMs focused on a topic and how much potential there is. High correlation would be a bigger focus but also currently less potential, as all OEMs are closer together. On the other hand, a weak correlation can be interpreted as a topic with less focus or more technical challenges that have yet to be overcome by some manufacturers. It also means, that this topic shows high potential for improvement for the OEMs with data underneath the regression lines.

\subsubsection{Development on Cell Level}

On cell level, there is a constant increase over the years and it can be seen that energy density improves similarly on cell as on system level about $110 \%$ gravimetrically and $85 \%$ percent volumetrically from 2010 to 2019 for non-Tesla vehicles (prismatic and pouch cells) (Figure 4). Tesla (cylindrical cells) has increased less but has started on a much higher level already 2013. Overall, the relatively strong correlations show, that the assessed manufacturers made use of newly improved cell performance altogether. In addition, circle markers represent cylindrical cells and " $\mathrm{X}$ " markers represent prismatic pouch and hard-case cells.

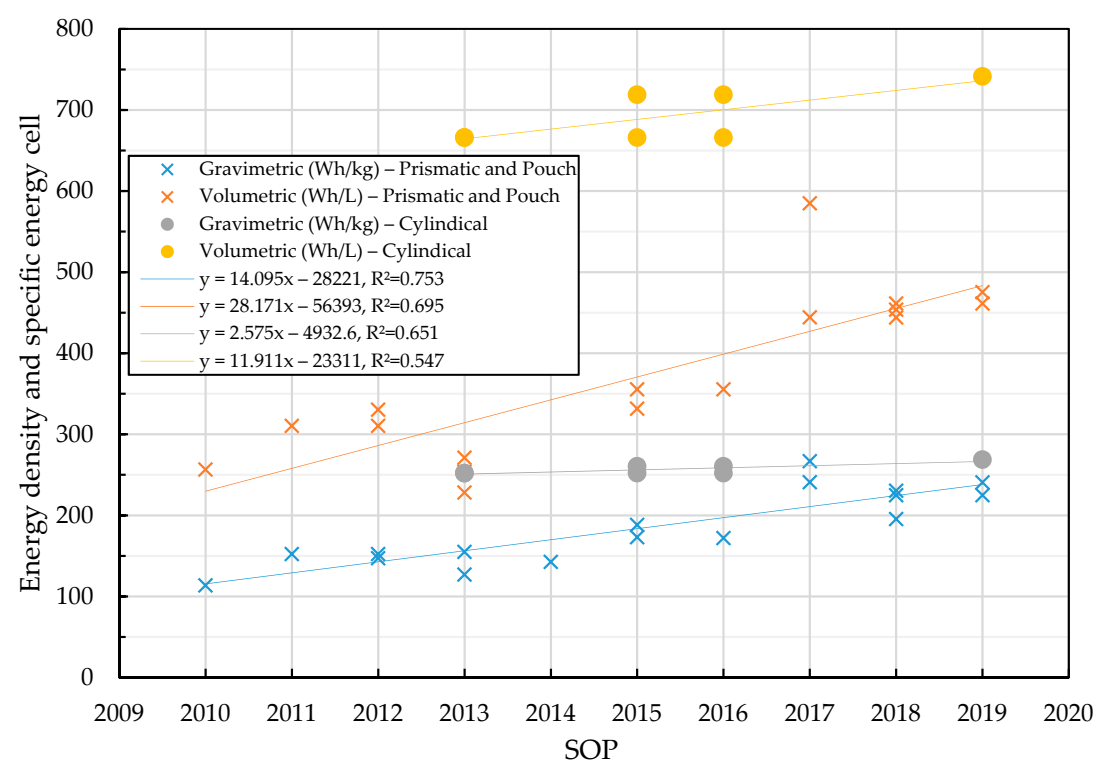

Figure 4. Development of specific energy $(\mathrm{Wh} / \mathrm{kg})$ and energy density $(\mathrm{Wh} / \mathrm{L})$ on cell level of various electric vehicles in the years between 2010 and 2019. Tesla with Cylindrical Cells shown separately.

\subsubsection{Development on Module Level}

Looking at the module level, one can also see a strong increase in specific energy and energy density over the years (Figure 5). 


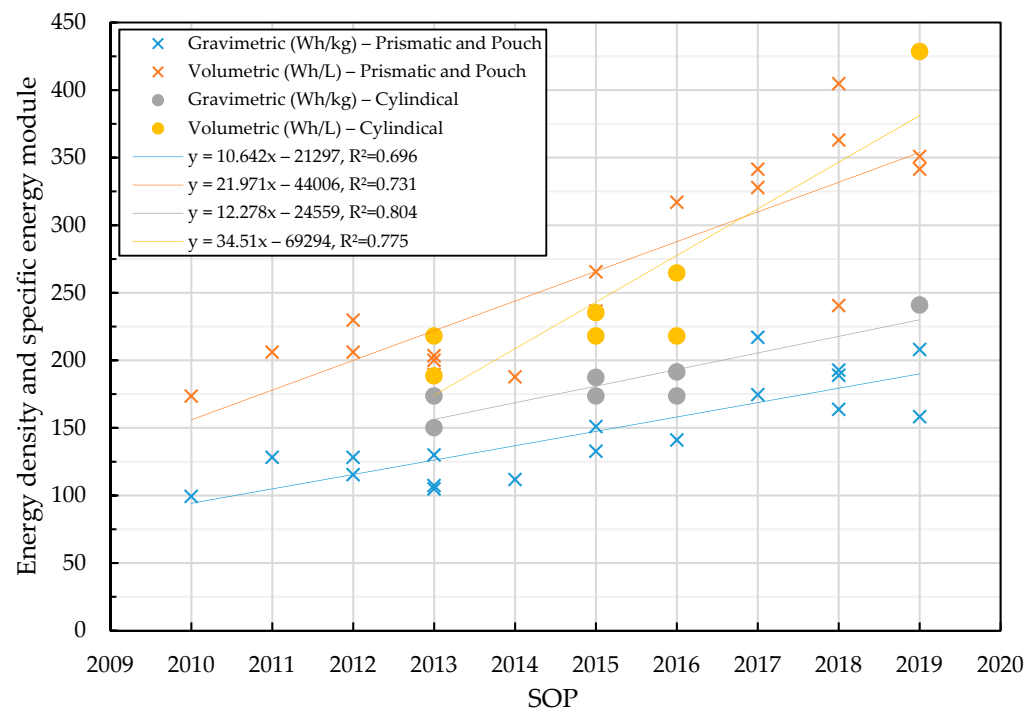

Figure 5. Energy density development on module level in the years between 2010 and 2019 .

Prismatic and pouch cell vehicles improved on a lower basis by about $100 \%$ volumetrically and gravimetrically. Cylindrical cell vehicles (Tesla) improved as well, although on a higher level: specific energy improved about $61 \%$, energy density by about $128 \%$ (calculated from Figure 5 ). This shows that they have increased their energy density much more than their specific energy which means that they focused more on packaging than on weight saving. This also correlates to the fact that cylindrical Tesla cells already in 2013 where much better than cells used in other vehicles and that they now made use of this cell potential even better.

\subsubsection{Development on System Level}

On system level (Figure 6), there is similarly to the module, a strong increase overall both in specific energy and energy density. However, the correlation coefficient $R^{2}$ of the energy density is much lower on a system level for pouch and prismatic cell vehicles than for the cylindrical cell vehicle manufacturer, Tesla. It shows, that gains made on module level are not always efficiently transferred to the system level by many different manufacturers.

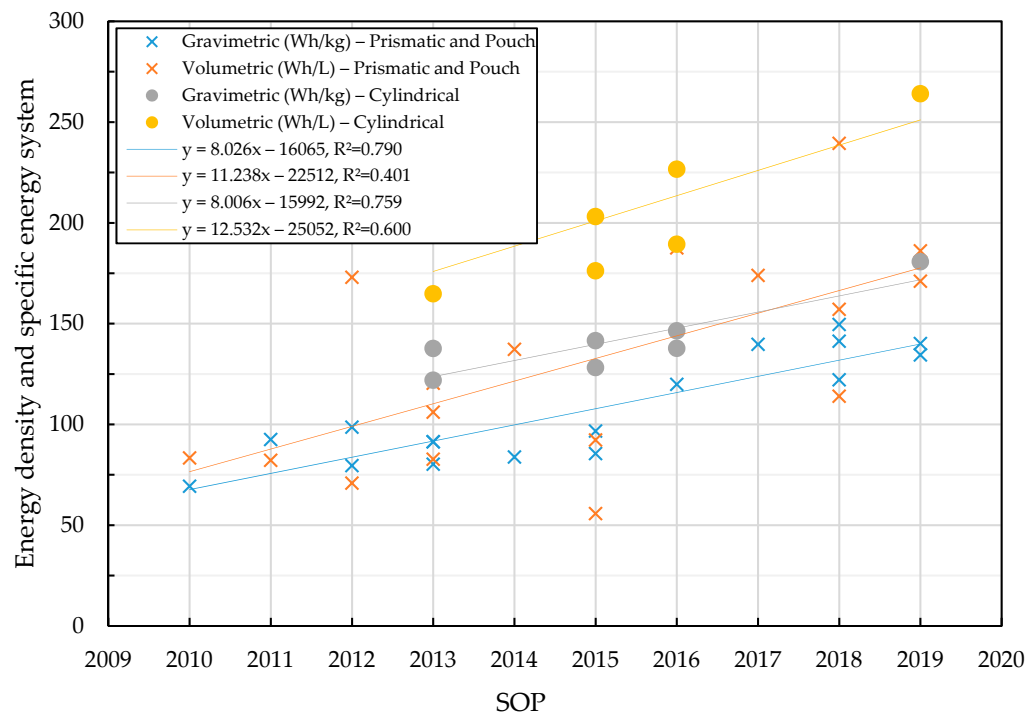

Figure 6. Development on system level in the years between 2010 and 2019. 


\subsection{Level Efficiency}

To analyse how efficient the OEMs can transfer the energy density of the cell level to the higher levels, a plot which compares these was constructed. Different from a Ragone plot [16] (p. 3), specific energy and energy density and not specific energy and power are plotted against each other. Three different combinations are possible: cell to module, module to system, and cell to system. As mentioned above, because cylindrical vehicles (Tesla) have very different values from other vehicles, they were separately categorized in the following figures as well, like in [15].

The goal of every OEM should be to aim for an efficiency rate of 1 between cell and system level. This means, when a cell for example has an energy density of $500 \mathrm{Wh} / \mathrm{L}$ the energy density of the system will also be $500 \mathrm{Wh} / \mathrm{L}$. In reality however, this is not possible. Due to cooling systems, battery management, contacting technology, sensors etc. the energy density decreases on every level. The efficiency rate can be calculated as follows:

$$
\text { efficiency rate }=\frac{\text { energy density of higher level (expl. : System })}{\text { energy density of lower level }(\text { expl. : Cell })}
$$

The same applies to the specific energy efficiency rate.

\subsubsection{Cell Level to System Level}

As Figure 7 implies that, the efficiency of the specific energy of all cell types, is higher than their energy density. It can also be noted that the gravimetric correlation is very high $\left(R^{2}=0.795\right.$ for pouch and prismatic cells; $R^{2}=0.824$ for cylindrical cells), the volumetric correlation of prismatic and pouch cell vehicles $\left(R^{2}=0.378\right)$ however is rather weak.

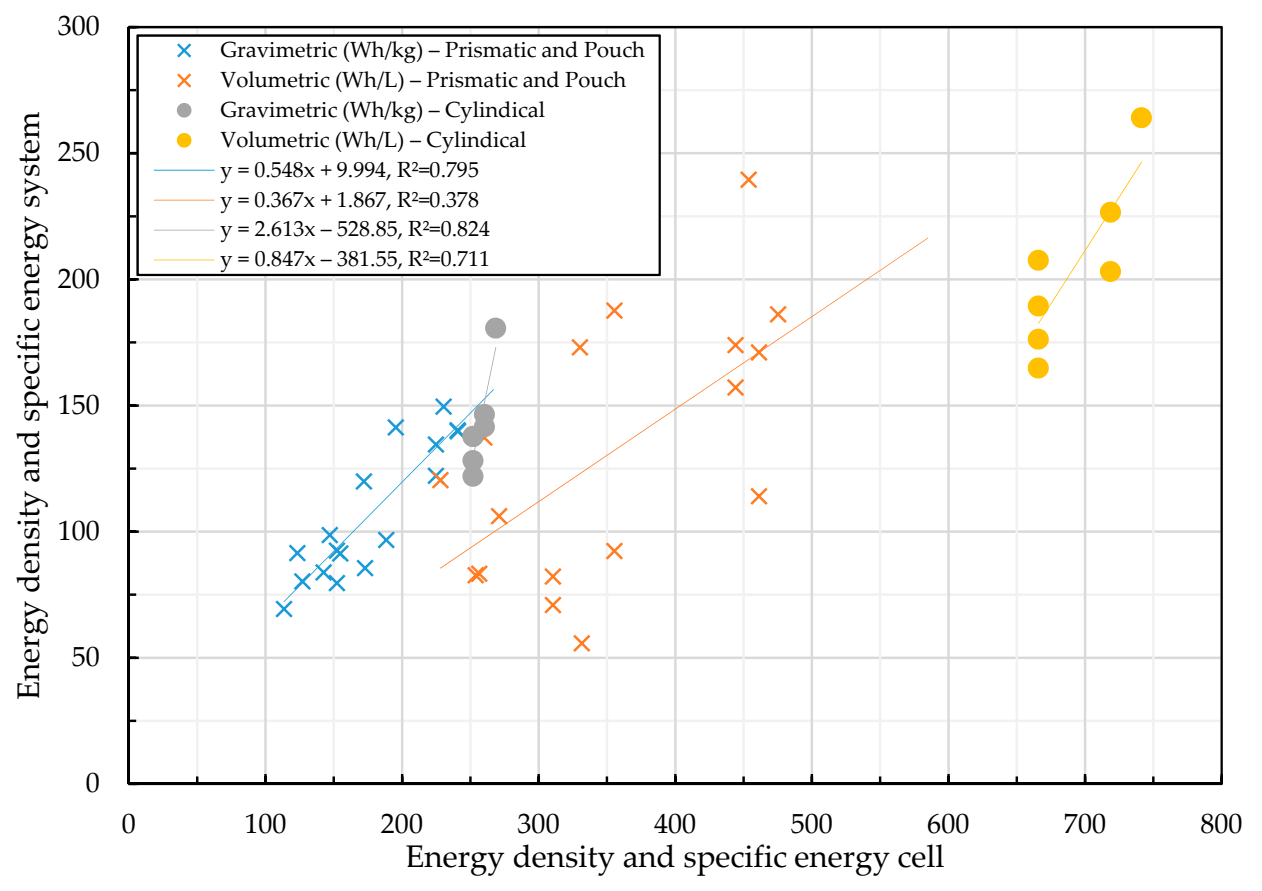

Figure 7. Scaling trend of energy density and specific energy on cell level vs. system level.

The efficiency rates are shown in Table 1 . To see where this efficiency gets lost, the two combinations cell to module, and module to system, need to be analyzed. 
Table 1. Efficiency rate of cell level to system level.

\begin{tabular}{ccccc}
\hline & $\begin{array}{c}\text { Gravimetric Prismatic } \\
\text { and Pouch }\end{array}$ & $\begin{array}{c}\text { Gravimetric } \\
\text { Cylindrical }\end{array}$ & $\begin{array}{c}\text { Volumetric Prismatic } \\
\text { and Pouch }\end{array}$ & $\begin{array}{c}\text { Volumetric } \\
\text { Cylindrical }\end{array}$ \\
\hline Average & 0.575 & 0.552 & 0.353 & 0.295 \\
Lowest & 0.495 & 0.484 & 0.168 & 0.247 \\
Highest & 0.742 & 0.672 & 0.528 & 0.356 \\
\hline
\end{tabular}

\subsubsection{Cell Level to Module Level}

Figure 8 shows the specific energy and energy density of the cell vs. the module. It can be observed, that on the one hand the correlation of all four regressions are very strong and range from $R^{2}=0.648$ to $R^{2}=0.885$. On the other hand, it is clearly visible why cylindrical cell vehicles were affecting the cell level in Figure 2 so much but not the other levels.

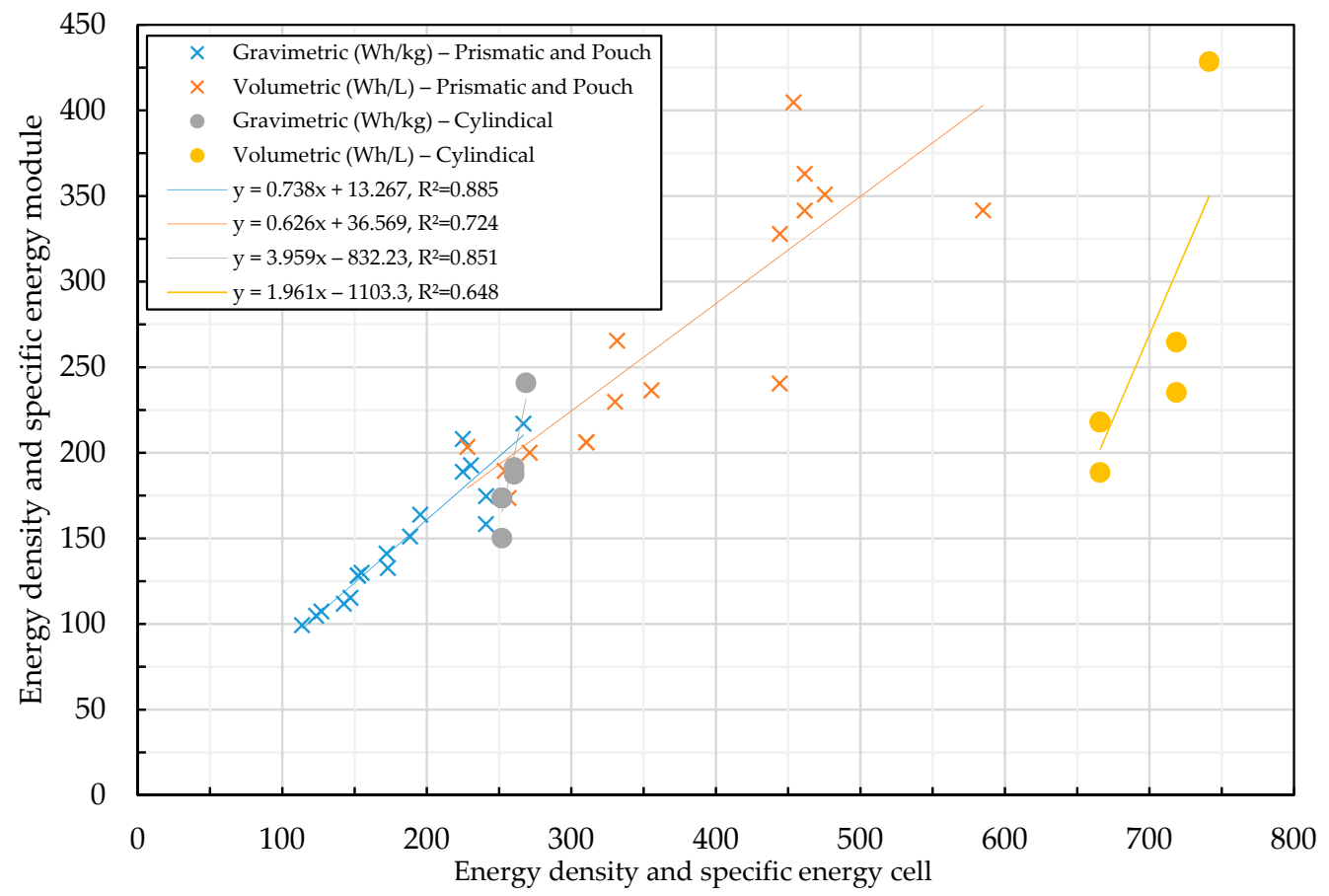

Figure 8. Scaling trend of energy density on cell level vs. energy density on module level.

Figure 4 shows that the volumetric density of cylindrical cells is by far the best. However, the volumetric energy density of the respective modules is on the same level as the other cell types. The gravimetric and volumetric regression lines of Pouch and prismatic cell vehicles show a similar slope and a similar correlation. Hence, the efficiency loss and the weak correlation seen in Figure 7 (cell to system) does not come from the losses from cell to module level.

The data shown in Table 2 underlines the findings in Figure 8. The efficiency rate for pouch and prismatic cell vehicles is in both cases above 0.73 . The volumetric efficiency rate of cylindrical cell vehicles is with 0.362 very low. The first conclusion made from this data, is that Tesla, which is the only manufacturer with round cells, has a lot of potential in further developing their modules. This is very likely due to the fact that the round cells can inherently be packed less dense than prismatic or pouch cells due to their shape. It is however important to mention again that cylindrical cell modules are not worse; they have about the same density as other battery modules. But because the cylindrical cells are leading in energy density on volumetric and gravimetric scale, the modules could be even better. 
Table 2. Efficiency rate of cell level to module level.

\begin{tabular}{ccccc}
\hline & $\begin{array}{c}\text { Gravimetric Prismatic } \\
\text { and Pouch }\end{array}$ & $\begin{array}{c}\text { Gravimetric } \\
\text { Cylindrical }\end{array}$ & $\begin{array}{c}\text { Volumetric Prismatic } \\
\text { and Pouch }\end{array}$ & $\begin{array}{c}\text { Volumetric } \\
\text { Cylindrical }\end{array}$ \\
\hline Average & 0.816 & 0.716 & 0.732 & 0.362 \\
Lowest & 0.658 & 0.595 & 0.541 & 0.283 \\
Highest & 0.926 & 0.897 & 0.892 & 0.578 \\
\hline
\end{tabular}

\subsubsection{Module Level to System Level}

Figure 9 shows again similar efficiency on gravimetric energy density. The gray and blue regression line both show a strong correlation $\left(R^{2}=0.731\right.$ for pouch and prismatic cell vehicles; $R^{2}=0.965$ for cylindrical cells in vehicles). The volumetric energy density looks different. While Tesla with their cylindrical cells was less efficient in bringing the good cell density to their modules, they are very efficient in bringing the module density to system level (volumetric efficiency rate $=0.834$, see Table 3 ). They also show a high correlation $\left(R^{2}=0.832\right)$ from cell to system. The volumetric energy density of other systems, show only weak correlations $\left(R^{2}=0.48\right)$ on module to system level. Also, the volumetric efficiency rate of these vehicles is with 0.477 almost half of the efficiency rate of cylindrical cell systems.

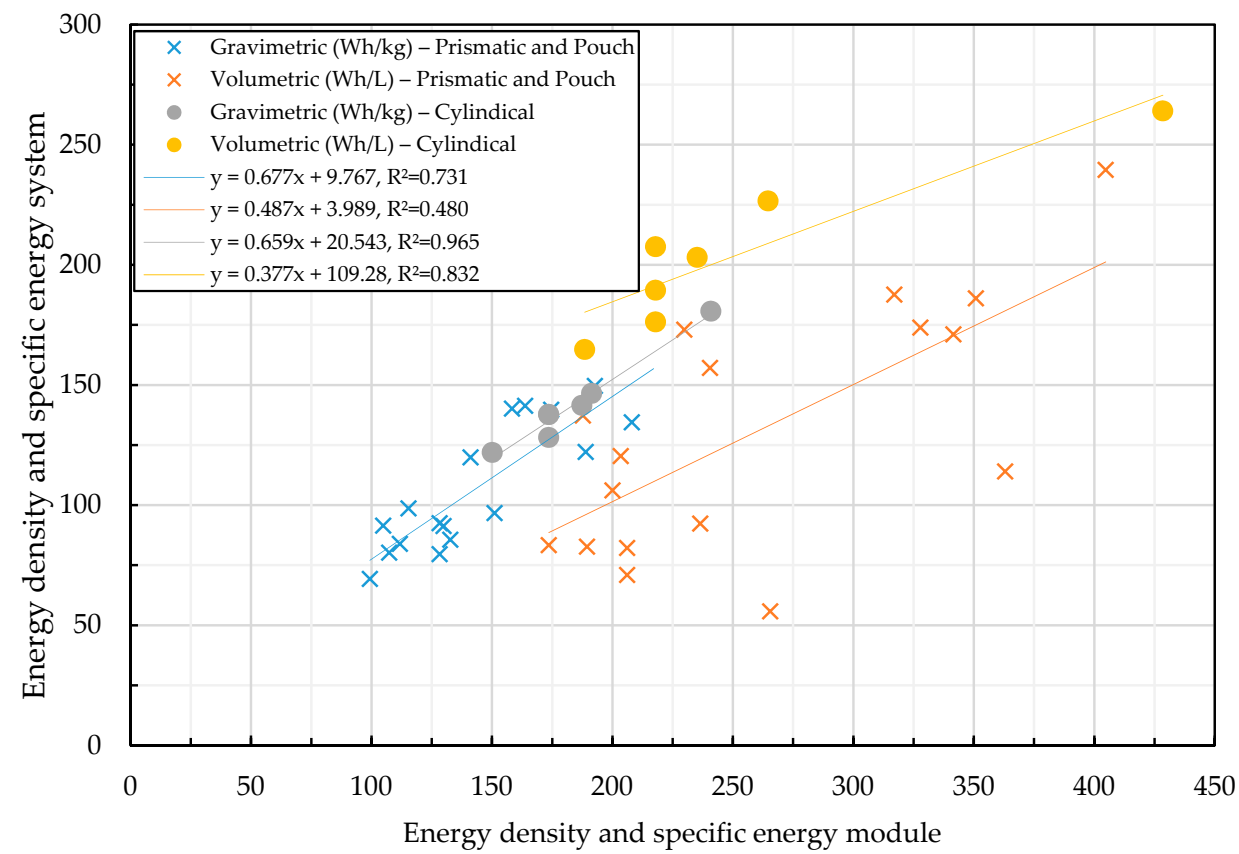

Figure 9. Scaling trend of energy density on module level vs. energy density on system level.

Table 3. Efficiency rate of module to system level.

\begin{tabular}{ccccc}
\hline & $\begin{array}{c}\text { Gravimetric Prismatic } \\
\text { and Pouch }\end{array}$ & $\begin{array}{c}\text { Gravimetric } \\
\text { Cylindrical }\end{array}$ & $\begin{array}{c}\text { Volumetric Prismatic } \\
\text { and Pouch }\end{array}$ & $\begin{array}{c}\text { Volumetric } \\
\text { Cylindrical }\end{array}$ \\
\hline Average & 0.706 & 0.772 & 0.477 & 0.834 \\
Lowest & 0.62 & 0.738 & 0.21 & 0.616 \\
Highest & 0.885 & 0.812 & 0.753 & 0.952 \\
\hline
\end{tabular}

Comparing the efficiency of the different levels, Figures 6-8 clearly show that the gravimetric energy density is on all levels similar in correlation and efficiency rate, for all cell type vehicles. The volumetric energy density on the other hand shows different correlations and different efficiencies on each level and between the cell shapes. Cylindrical cells have a higher volumetric and gravimetric density. However, they lose this advantage due to a low volumetric efficiency rate between cell and 
module level (0.362). The volumetric efficiency rate between module and system level is on the other hand very good. For pouch and prismatic cell vehicles, it is the other way around. While Tesla with its cylindrical cells has a weak volumetric efficiency rate between cell and module, the other vehicles have a twice as high volumetric efficiency rate (0.732). However, between module and system level, the volumetric efficiency rate is lower (Cylindrical: 0.834; Prismatic and Pouch: 0.477). The regression in Figure 9 between these levels shows also the weak correlation $\left(R^{2}=0.48\right)$ which explains where the weak correlation in Figure 7 comes from.

From Figures 7-9 can be concluded, that the gravimetric energy density has already been focus of most OEMs, seen by relatively high efficiency rates and strong correlations on all three levels. The volumetric energy density does not show these constant efficiency rates on all levels. Hence, some OEMs show a lot of room for improvements especially between module and system level.

\subsubsection{Cell Size}

In KERLER, one of the conclusions is that there is no universal possibility of determining an optimal battery cell size for electric vehicles because the influence through boundary conditions of the specific system is very strong [17]. However, the industry trend seems to be converging to at least slightly higher cell capacity since energy density increases and cell size at least stays the same. An extreme example of this is the BMW i3 where the cell capacity more than doubled towards $120 \mathrm{Ah}$ [12] over the years whereas cell size stayed the same. Other novel announced designs that are not yet available on the market have cell sizes that are so large, that the module level is skipped like the BYD "Blade Battery" [18] or the CATL "Cell to Pack" System [19]. These are not included in the data. This would mean that the module level could be skipped entirely and one integration level falls away which by itself would strongly increase energy density and specific energy.

As can be seen from Figure 10, there is no universal trend in cell size for new vehicles in the assessed data-however maximum cell sizes seems to be going up continuously which fits with announcements mentioned above. Also, plotting cell energy vs. system specific energy does not reveal any strong correlations between dense and less dense systems.
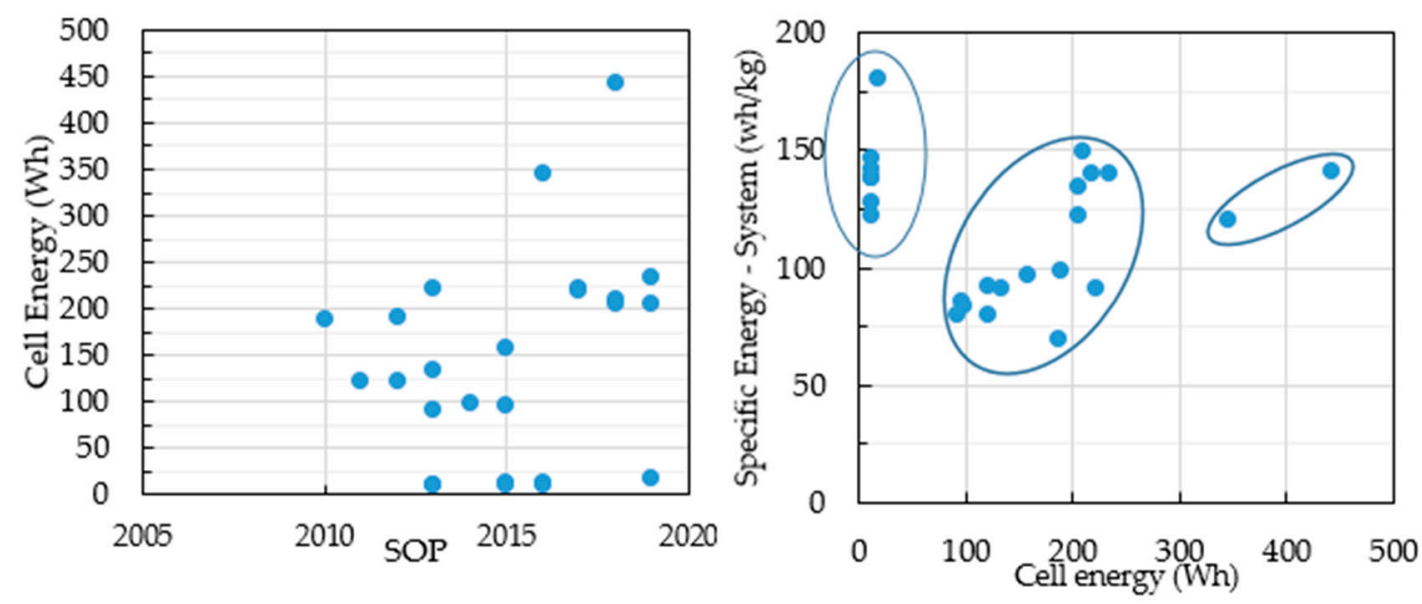

Figure 10. SOP vs. Cell Energy and Cell Energy vs. Specific Energy on System Level.

However, one could identify three groups: very small cells, medium sized cells and a few very large cells that increase system specific energy with size. Very small and very large cells seem to be advantageous-medium sized cell vary widely in their specific energy with an significant increase in specific energy for cells above $200 \mathrm{Wh}$. Overall, no clear conclusions can be drawn and it seems to be a matter of system design quality how much of a cell is "left" on system level. Doing the same comparison with energy density does not reveal significant differences. 


\subsubsection{Cell Type}

All three cell types have been integrated into series production system designs. This shows that none of their distinctions is so good or bad that this makes them superiorly attractive or unfitting. It is noteable that Tesla is the only vehicle manufacturer that has been using cylindrical cells in large scale EV applications. The other manufacturers employed prismatic hard case or pouch cells. The round cells have a packaging disadvantage and this shows clearly when comparing energy density between cell and module level for the various systems. The use of these round cells comes from Tesla's history of employing laptop battery cells for their original Tesla Roadster, their first vehicle. However, even Tesla is announcing to introduce non-cylindrical cells to their vehicles [20].

In the book by Arora et al. [14] (p. 183) criteria for structural characteristics of battery cells are assessed and small cylindrical cells are ascribed to only good, but not excellent "appropriateness for production runs." This seems not to represent reality as especially Tesla is producing at the largest scale. Another relevant criteria in Arora et al. [14] is safety of a cell type, where pouch cells are described as performing poorly in this regard compared to the others. However, since they are used widely as well, this assessment is either untrue or safety can be increased to an adequate level on a module level. "Field replaceability", which means the ability to replace individual cells in a pack during its lifetime not in the factory, is another criteria that is only "possible" with prismatic hard-case cells, according to the source Arora et al. [14]. This also seems not to have played out this way-none of the cell types is being replaced individually in the field in current OEM battery systems because no real incentives exist and it is technically hard to do so [21], (p. 2).

When looking at the data (specific energy and cell type, Figure 11), one can see that prismatic cells have a slightly lower energy density than pouch cells and these two a significantly lower energy density on system level than the cylindrical cell. As shown above in Figure 11, the difference is smaller than the difference in specific energy on cell level because round cells can be packed less optimally. From this data, an existing advantage for the cylindrical cell can be seen, but it could be eroded by larger and larger prismatic and pouch cells or even a cell to pack system which would not be as advantageous with cylindrical cells.

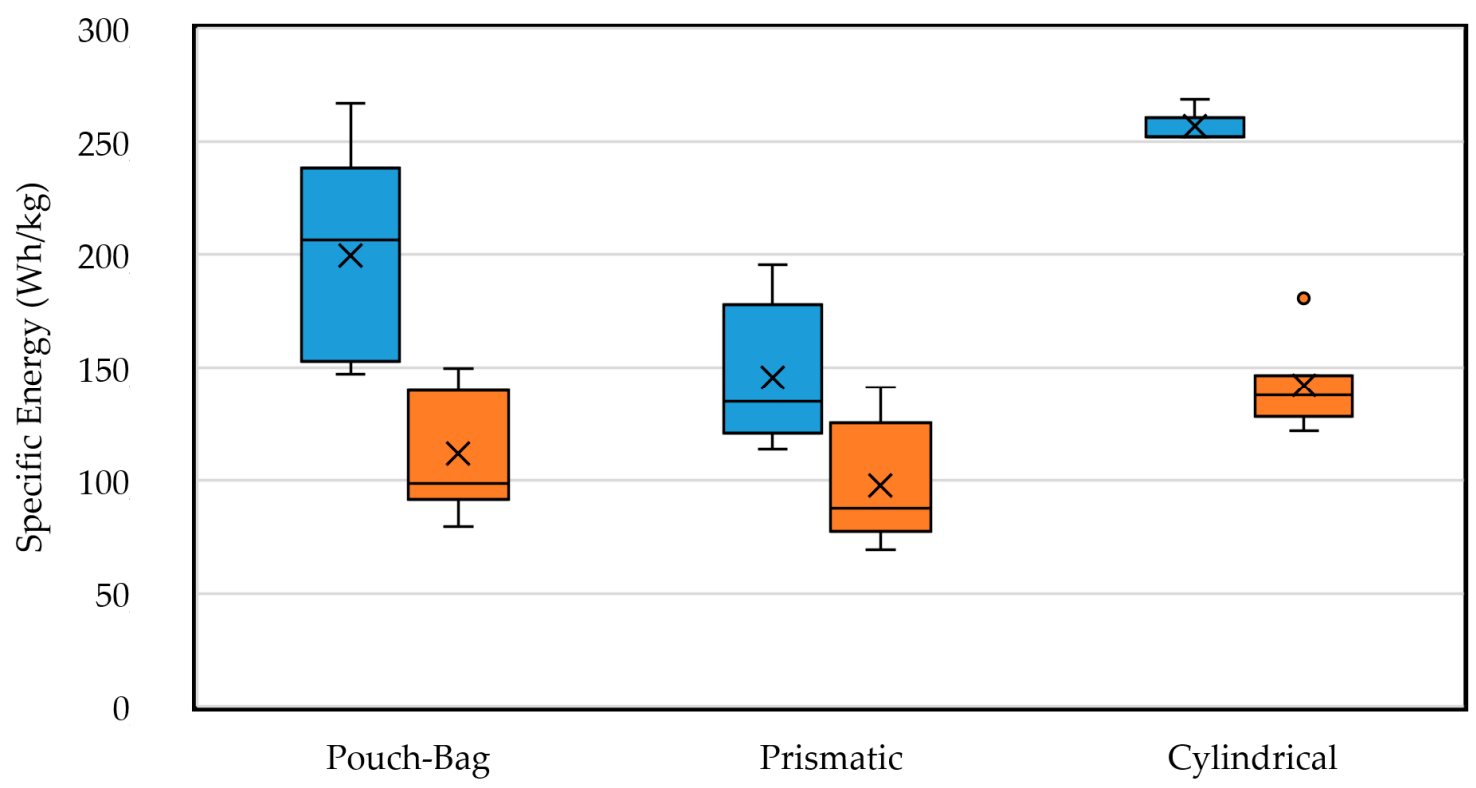

Figure 11. Cell Type and Energy Density on Cell Level (Blue) and System Level (Orange) from the 25 Vehicles Assessed. 


\section{Discussion and Conclusions}

The data analysis brought many relevant insights. One specific result of the assessment is that specific energy on system level is seems to be mainly a question of cell chemistry; the cell mass fraction between different systems stays relatively similar-much more so than energy density: Looking at the data, it becomes clear that many systems assessed have a quite low energy density as compared to their cell energy density and that the range of energy density between vehicles is very high. Especially the influence of efficient packaging is very strong for reaching high driving ranges because spare volume is scarce in vehicle design and packaging is not always done very efficiently, but efficient packaging means more space for cells. To make use of this, many tools like [22] exist to build digital mock-ups of various cell arrangements for efficient comparison.

It has to be noted, that the efficient use of the available space also has further advantages: less space means less material used on housing and other components and then less weight for the battery system which further increases range and can even help reduce the sizing of other components because their strength can be lower because of a more compact and lighter battery system. This effect is also known as the "negative weight spiral" [23]. It is also expected that when cells get cheaper and cheaper, reducing system size and making use of the "weight spiral" can be a further differentiating and also cost saving factor for battery system designers.

But how good can we expect current systems under ideal integration to get? The best system available today has a specific energy of $181 \mathrm{Wh} / \mathrm{kg}$. If one were to take the best cell-to module efficiency (0.926) and the best module to system efficiency $(0.885)$ and the cell with the highest specific energy $(269 \mathrm{Wh} / \mathrm{kg})$, already current system designs could have $220 \mathrm{Wh} / \mathrm{kg}$. This were to be an improvement of $22 \%$. For the energy density a similar thought experiment is possible: the current best system has $264 \mathrm{Wh} / \mathrm{L}$, the best cell has $741 \mathrm{Wh} / \mathrm{L}$. Taking the efficiencies like above (0.892/0.952), one would end up with a system that has a staggering $629 \mathrm{Wh} / \mathrm{L}$. However, this theoretical value can be limited by other factors such as cooling system layout necessities for different cell types or module and system configuration limitations but shows the potential that might be possible.

Also, other limits to the study exist that need to be taken in to account: All the data is a best assessment from the external sources available, not from an own assessment of actual vehicles. Especially volumetric data can have inaccuracies because it is not known whether the displacement volume or the box volume is given for the system components. However, since shapes of modules and systems is overall prismatic in most cases, this should not alter the results significantly. Furthermore, the integration of a system into a pack is a factor that can especially influence gravimetric data. If the battery system design is made to increase the stiffness of the entire vehicle body, the battery housing needs to be much stronger than a battery system housing that relies on the strength of the vehicle structure. The influence of this on weight is difficult to quantify. But given the fact that all battery systems themselves have to pass some sort of mechanical certification tests like the ECE R 100 [24], a similar minimum stiffness between systems can be expected. Also, power requirements can vary greatly depending on the vehicle, and thus the size of the cooling system of the battery could affect overall system size and weight strongly and increase the volume especially for larger premium vehicles.

For future research, more assessments are possible: when Cell-to-Pack technology hits the market, it will be insightful to analyze the real-world benefits of this design concept. Also correlations between vehicle power and cooling system strategies could be taken into account when better data becomes available for this.

Compared to other studies about battery system configurations, this study has the advantage of using up-to-date real-world data and not assessments of single systems or hypothetical configurations that exist in prototype vehicles or digital mock-ups but not in large vehicles; also not only the cell and the system are compared, but also the module level. It is possible to use the results of this design assessment study for various purposes. For battery system designers, initial estimations for package density assessments can be made and cell choices can be supported by comparison to current real-world battery systems. The study also shows the limits in packing density that can be achieved with current 
system designs and thus helps to define the boundaries of possible system performance values like weight, size or energy content and thus helps advance battery system development.

Author Contributions: Conceptualization, H.L.; Funding acquisition, H.H.; Investigation, H.L. and J.R.; Methodology, H.L. and S.W.; Resources, H.H.; Supervision, S.W. and A.K.; Visualization, J.R.; Writing-original draft, H.L. and J.R.; Writing-review \& editing, S.W., C.O. and M.K. All authors have read and agreed to the published version of the manuscript.

Funding: This research was funded by Federal Ministry of Education and Research, grant number 3XP0113D-HiT-Cell.

Acknowledgments: Further support in data sorting and visualization was provided by Hüseyin Karakas.

Conflicts of Interest: The authors declare no conflict of interest.

\section{Appendix A}

Table A1. Collected Data.

\begin{tabular}{ccccc}
\hline Vehicle Name & Vehicle Manufacturer & Year of Market Entry & Vehicle Weight & Vehicle Class \\
Cell Type & Nominal Voltage & Cell Manufacturer & Cell Capacity & Module Size \\
Module Weight & Module Configuration & System Configuration & System Size & System Weight \\
\hline
\end{tabular}

Table A2. Estimated and calculated values.

\begin{tabular}{|c|c|c|c|c|}
\hline Energy Density & Specific Energy & System Voltage & $\begin{array}{c}\text { Cell to Module Ratio } \\
\text { (gravimetric and volumetric) }\end{array}$ & Cell to Pack Ratio \\
\hline
\end{tabular}

Table A3. Vehicle Data Sources.

\begin{tabular}{|c|c|c|c|c|}
\hline Manufacturer & Car Name & Vehicle Class & Market Entry & Main Data Sources \\
\hline BMW & i3-Gen 1 & Middle Class Vehicle & 2013 & Internet, Conference (AABC 2014, 2019 Asia), B3 Report \\
\hline BMW & i3-Gen 2 & Middle Class Vehicle & 2016 & Internet, Conference (AABC 2014, 2019 Asia), B3 Report \\
\hline BMW & i3-Gen 3 & Middle Class Vehicle & 2018 & Internet, Conference (AABC 2014, 2019 Asia), B3 Report \\
\hline Daimler & Smart for two & Compact Vehicle & 2012 & $\begin{array}{c}\text { Internet, Conferences (AABC } 2018 \text { Europe \& Battery } \\
\text { Experts Forum 2016) }\end{array}$ \\
\hline Jaguar & I-Pace & Middle Class Vehicle & 2018 & Internet, Paper (ATZ), B3 Report \\
\hline Mitsubishi & iMiEV & Compact Vehicle & 2010 & Conference (AABC 2013), B3 Report, Internet \\
\hline Nissan & Leaf $24 \mathrm{kWh}$ & Middle Class Vehicle & 2012 & Internet, US DoE \\
\hline Nissan & Leaf $30 \mathrm{kWh}$ & Middle Class Vehicle & 2015 & Conferences (AABC Asia 2014), Internet, B3 Report \\
\hline Nissan & Leaf $40 \mathrm{kWh}$ & Middle Class Vehicle & 2018 & Internet, B3 Report \\
\hline Nissan & Leaf $62 \mathrm{kWh}$ & Middle Class Vehicle & 2019 & Internet, B3 Report \\
\hline Renault & Kangoo Z.E. & Middle Class Vehicle & 2011 & B3 Report \\
\hline Renault & Zoe Gen 1 & Compact Vehicle & 2013 & B3 Report \\
\hline Renault & Zoe Gen 2 & Compact Vehicle & 2017 & B3 Report \\
\hline Renault & Zoe Gen 3 & Compact Vehicle & 2019 & B3 Report \\
\hline Tesla & Model S 60 & Luxury Vehicle & 2013 & Conference (AABC 2019 Asia), B3 Report \\
\hline Tesla & Model S 70 & Luxury Vehicle & 2015 & Conference (AABC 2019 Asia), B3 Report \\
\hline Tesla & Model S 75 & Luxury Vehicle & 2016 & Conference (AABC 2019 Asia), B3 Report \\
\hline Tesla & Model S 85 & Luxury Vehicle & 2013 & Conference (AABC 2019 Asia), B3 Report \\
\hline Tesla & Model S 90 & Luxury Vehicle & 2015 & Conference (AABC 2019 Asia), B3 Report \\
\hline Tesla & Model S P100D & Luxury Vehicle & 2016 & Conference (AABC 2019 Asia), B3 Report \\
\hline Tesla & Model 3 Performance & Middle Class Vehicle & 2019 & B3 Report \\
\hline VW & e-up & Compact Vehicle & 2013 & B3 Report \\
\hline GM & Spark & & 2015 & B3 Report \\
\hline Opel & Ampera-e & Middle Class Vehicle & 2017 & B3 Report \\
\hline VW & e-Golf & Middle Class Vehicle & 2014 & Internet \\
\hline
\end{tabular}




\section{References}

1. European Union. $\mathrm{CO}_{2}$ Emission Performance Standards for Cars and Vans (2020 Onwards)-Climate Action-European Commission. Available online: https:/ec.europa.eu/clima/policies/transport/vehicles/ regulation_en (accessed on 2 December 2020).

2. Bernhart, W.; Olschewski, I.; Busse, A.; Riederle, S.; Pieper, G.; Hotz, T. E-Mobility Index 2019; Roland Berger-Automotive Competence Center \& fka GmbH: Munich, Germany, 2019.

3. Henze, V. Battery Pack Prices Fall as Market Ramps up with Market Average at $\$ 156 / \mathrm{kWh}$ in 2019|BloombergNEF. Available online: https://about.bnef.com/blog/battery-pack-prices-fall-as-marketramps-up-with-market-average-at-156-kwh-in-2019/ (accessed on 2 May 2020).

4. Nykvist, B.; Sprei, F.; Nilsson, M. Assessing the progress toward lower priced long range battery electric vehicles. Energy Policy 2019, 124, 144-155. [CrossRef]

5. Hettesheimer, T.; Tübke, J.; Möller, K.-C. Entwicklungsperspektiven für Zellformate von Lithium-IonenBatterien in der Elektromobilität. Available online: https:/www.batterien.fraunhofer.de/content/dam/ batterien/de/documents/Allianz_Batterie_Zellformate_Studie.pdf (accessed on 7 December 2020).

6. Cano, Z.P.; Banham, D.; Ye, S.; Hintennach, A.; Lu, J.; Fowler, M.; Chen, Z. Batteries and fuel cells for emerging electric vehicle markets. Nat. Energy 2018, 3, 279-289. [CrossRef]

7. Kwade, A.; Haselrieder, W.; Leithoff, R.; Modlinger, A.; Dietrich, F.; Droeder, K. Current status and challenges for automotive battery production technologies. Nat. Energy 2018, 3, 290-300. [CrossRef]

8. Lain, M.J.; Brandon, J.; Kendrick, E. Design Strategies for High Power vs. High Energy Lithium Ion Cells. Batteries 2019, 5, 64. [CrossRef]

9. Bloch, C.; Newcomb, J.; Shiledar, S.; Tyson, M. Breakthrough Batteries. Powering the Era of Clean Electrification. Available online: https://www.pnas.org/content/117/23/12550 (accessed on 2 December 2020).

10. Stoikou, E.; Frith, J.F.; Goldie-Scot, L. Next-Generation Lithium Battery Technology Advancements; BloombergNEF: New York, NY, USA, 2019.

11. Takeshita, H. LIB-Equipped Vehicle Market Bulletin (14Q4) and Long-Term Total LIB Demand Forecast; B3 Report 14-15; B3 Corporation: Tokyo, Japan, 2015; Chapter 8.

12. Brunckhorst, P. Technische Daten BMW i3 (120Ah): Medieninformation; BMW AG: München, Germany, 2018.

13. Heimes, H.; Kampker, A.; Lienemann, C.; Locke, M.; Offermanns, C. Produktionsprozess einer Lithium-IonenBatteriezelle, 3. Auflage; VDMA: Frankfurt, Germany, 2019; ISBN 978-3-947920-00-6.

14. Arora, S.; Kapoor, A. Mechanical Design and Packaging of Battery Packs for Electric Vehicles. In Behaviour of Lithium-Ion Batteries in Electric Vehicles: Battery Health, Performance, Safety, and Cost; Pistoia, G., Liaw, B., Eds.; Springer: Cham, Switzerland, 2018; pp. 175-200. ISBN 978-3-319-69950-9.

15. Jung, H.S.; Silva, R.; Han, M. Scaling Trends of Electric Vehicle Performance: Driving Range, Fuel Economy, Peak Power Output, and Temperature Effect. World Electr. Veh. J. 2018, 9, 46. [CrossRef]

16. Ragone, D.V. Review of Battery Systems for Electrically Powered Vehicles. In Technical Paper Series, Proceedings of the Mid-Year Meeting, Detroit, MI, USA, 20 May 1968; Society of Automotive Engineers, Ed.; SAE International: New York, NY, USA, 1968; pp. 1-9.

17. Matthias Manuel Kerler. Eine Methode zur Bestimmung der Optimalen Zellgröße für Elektrofahrzeuge, 1st ed.; Verlag Dr. Hut: München, Germany, 2018; ISBN 978-3-8439-3948-5.

18. BYD. BYD's New Blade Battery Set to Redefine EV Safety Standards-BYD USA. Available online: https://en.byd.com/news-posts/byds-new-blade-battery-set-to-redefine-ev-safety-standards/ (accessed on 12 June 2020).

19. XINHUA. China's CATL Unveils Cell-to-Pack Battery Platform-Xinhua|English.news.cn. Available online: http://www.xinhuanet.com/english/2019-09/13/__138389934.htm (accessed on 12 June 2020).

20. Mattke, S. Neue Billig-Batterie aus China Zeigt: Tesla hat bei Akku-Kosten vier Jahre Vorsprung. Teslamag. 20 May 2020. Available online: https:/teslamag.de/news/neue-billig-batterie-china-tesla-akku-kosten-vierjahre-vorsprung-28443 (accessed on 12 June 2020).

21. Kampker, A.; Wessel, S.; Fiedler, F.; Maltoni, F. Battery pack remanufacturing process up to cell level with sorting and repurposing of battery cells. J. Remanufacturing 2020, 241, 680. [CrossRef]

22. Stefaniak, T.; Maiwald, D.; Püschel, G.; Grote, K.-H. Auslegung von Energiespeichern in Elektrofahrzeugen mittels Digital Mock-Up bei dezentralisierten Antriebssträngen. KT Kolloquium 2017, 15, 255-266. 
23. Trautwein, T.; Henn, S.; Rother, K. Gewichtsspirale. ATZ Automobiltechnische Zeitschrift 2011, 113, $390-395$. [CrossRef]

24. Uniform Provisions Concerning the Approval of Vehicles with Regard to Specific Requirements for the Electric Power Train; [2015/505]. ECE R 100; Publications Office of the EU: Brussels, Belgium, 2015; Available online: https://op.europa.eu/s/n81W (accessed on 7 December 2020).

Publisher's Note: MDPI stays neutral with regard to jurisdictional claims in published maps and institutional affiliations.

(C) 2020 by the authors. Licensee MDPI, Basel, Switzerland. This article is an open access article distributed under the terms and conditions of the Creative Commons Attribution (CC BY) license (http://creativecommons.org/licenses/by/4.0/). 